\title{
VOLUME 20
}

NUMBER 4

\section{3}

\section{ontents}

\section{Articles}

A Longitudinal Study of Developmental Differences in Universal Preventive Intervention for Child Anxiety

Sally Lock and Paula M. Barrett

The "Anti-monster Letter" as a Simple Therapeutic Tool for Reducing Night-time Fears in Young Children

Peter Muris, Cindy Verweij and Cor Meesters

The Social Validity of Interventions for Promoting Preschool Children's Peer Interactions

David Hamilton and Aphrodite Zoitas

Contributions to Rehabilitation from Behavioural Psychology: Then and Now

Gregory C. Murphy, Amanda E. Young and Katharine Reid

Effects of Thought Suppression on Subliminally and Supraliminally Presented Food-related Stimuli

Peter J.N. Dejonckheere, Caroline Braet and Barbara Soetens

\section{Review}

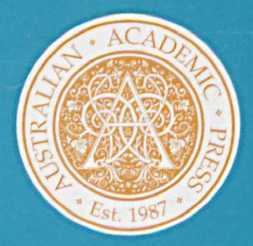

